\title{
Use of modified-citrate tube to rectify spurious coagulopathy in smoker's polycythaemia: medical resolution of a dentist's dilemma
}

\author{
Tushar Sehgal (10, ${ }^{1}$ Aditi Nanda, ${ }^{2}$ Shyam Prakash, ${ }^{1}$ Arulselvi Subramanian ${ }^{1}$
}

${ }^{1}$ Laboratory Medicine, All India Institute of Medical Sciences, New Delhi, Delhi, India ${ }^{2}$ Prosthodontics, CDER, All India Institute of Medical Sciences, New Delhi, Delhi, India

Correspondence to Dr Tushar Sehgal; doctusharsehgal@yahoo.co.in

Accepted 5 December 2021

Check for updates

(C) BMJ Publishing Group Limited 2022. No commercial re-use. See rights and permissions. Published by BMJ.

To cite: Sehgal T, Nanda A Prakash $\mathrm{S}$, et al. BMJ Case Rep 2022;15:e246102. doi:10.1136/bcr-2021246102

\section{DESCRIPTION}

A 30-year-old man came to the dental clinic for tooth extraction. The dental surgeon observed the coagulation profile and found an increased prothrombin time (PT) of $16.7 \mathrm{~s}$ (range 9-14 s) and activated partial thromboplastin time (APTT) of 44.2 s (range 27-39 s). Both PT and APTT were performed on STA R Max3 (Diagnostica Stago France) automated coagulation analyser using citrate vials [BD Vacutainer plastic citrate tubes of $2.7 \mathrm{~mL}(0.109 \mathrm{M}, 3.2 \%$ buffered sodium citrate)] with STA-NeoPTimal reagent for PT and STA -Cephascreen for APTT. Suspecting a clotting abnormality, the patient was referred to a specialised coagulation laboratory for further evaluation. There was neither a previous bleeding episode nor any bleeding disorder in his family. Complete blood count showed haemoglobin of $18.7 \mathrm{~g} / \mathrm{L}$, haematocrit of $56.3 \%$, red blood cell (RBC) count of $6.75 \times 10^{9} / \mathrm{L}$, white cell of $10.8 \times 10^{9} / \mathrm{L}$ and platelet count of $375 \times 10^{9} / \mathrm{L}$. The haematocrit and RBC counts were elevated for age and gender. On further enquiry, the patient's personal history was significant for chronic cigarette smoking for the last 8 years. The laboratory specialist suspected secondary polycythaemia (smokers' polycythaemia) behind the abnormal results. The blood sample in the blue top tube confirmed high haematocrit (figure 1). To maintain an anticoagulant to plasma ratio of $1: 9$, $0.1 \mathrm{~mL}$ of the citrate was removed from the vial and a blood sample was collected afresh in the modified vial. ${ }^{1}$ Repeat tests were within normal limits. The latest results were communicated to the patient and the surgeon. The preanalytical variable of high haematocrit resulted in erroneous clotting results, thereby causing a delay in surgical extraction of the affected tooth.

Despite advances in laboratory instrumentation incorrect or inappropriate test results are occasionally reported to clinicians, most often due to circumstances beyond the control of the laboratories performing the tests. ${ }^{2}$ The term 'preanalytical phase' includes all aspects of medical laboratory diagnostic procedure that occurs before the analytical phase. Preanalytical variables can arise at any point before sample testing, including sample collection, handling, transportation, processing and storage. Due to this, it is the most vulnerable part of the total testing process, where most laboratory errors occur. ${ }^{3}$ However, not all factitious test results and laboratory errors necessarily transcribe into significant harm for the patient. Nonetheless,

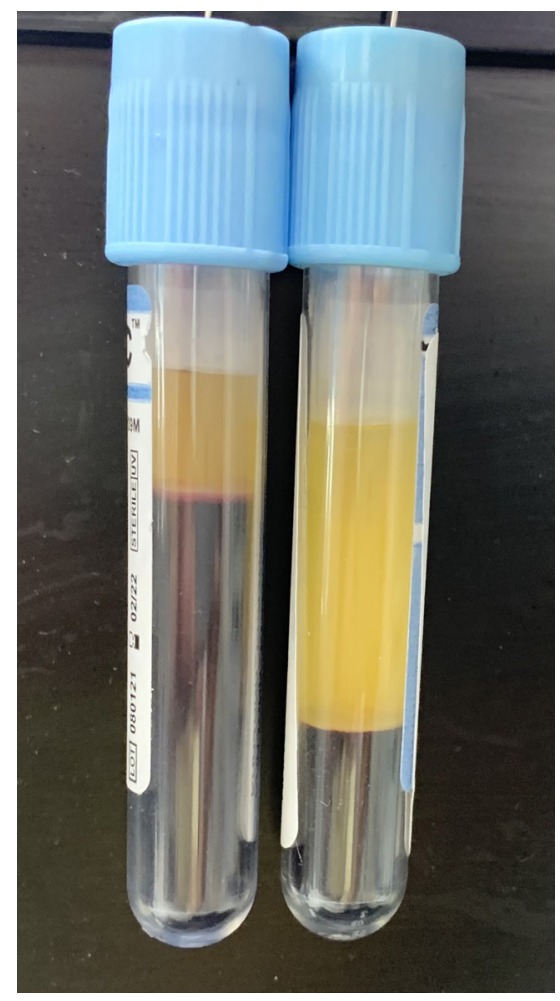

Figure 1 Two blue-top vials are depicted. The vial on the left shows the index case with high haematocrit while the vial on the right is from a patient with normal haematocrit (kept for comparison).

the consequences of incorrect test results might still be clinically worthwhile and lead to several unwanted clinical outcomes or adverse economic consequences, especially in resource-constraint settings. ${ }^{4}$ Blood samples with high haematocrits like those seen in neonates, severe dehydration, burn patients, polycythaemia vera, smokers, high altitude residents may result in factitiously elevated clotting times. This happens as excess citrate in the sample relative to plasma binds to the calcium that is added to the clotting assay via the testing reagent. Calcium, an essential requirement for the clotting process is thus unavailable, hence clotting times are spuriously prolonged. Laboratories may create vacuum tubes with a reduced volume of the anticoagulant to overcome the issue of a high haematocrit. Alternatively, the appropriate citrate may be removed and the tube recapped as was done in this case. ${ }^{5}$ The method used for adjusting citrate concentrations needs to be validated by each laboratory before use. 
In the current case, falsely prolonged 'screening' coagulation test influenced a clinical decision to undertake further investigations causing unnecessarily delay in the surgery and raising anxiety in the patient. Knowledge about this preanalytical issue prevented unwarranted diagnostic workup including mixing studies, testing for factor assays and inhibitors.

\section{Patient's perspective}

I was amazed on understanding how my increased haematocrit had caused the laboratory error. My anxiety and distress were finally relieved on knowing that the clotting results were within normal limits and I could safely undergo my dental extraction.

\section{Learning points}

Preanalytical phase is the most vulnerable part of the total testing process.

- Laboratory physician must be careful in interpreting unadjusted samples with high haematocrit.

- In patients with high haematocrit, the citrate concentrations must be adjusted for accurate results.

Contributors All authors participated in conception and design, acquisition of data or analysis and interpretation of dataTS drafted the article. AN, SP and AS revised it critically for important intellectual content.All authors gave final approval of the version published.All authors give agreement to be accountable for the article and to ensure that all questions regarding the accuracy or integrity of the article are investigated and resolved.

Funding The authors have not declared a specific grant for this research from any funding agency in the public, commercial or not-for-profit sectors.

Competing interests None declared.

Patient consent for publication Consent obtained directly from patient(s).

Provenance and peer review Not commissioned; externally peer reviewed.

Case reports provide a valuable learning resource for the scientific community and can indicate areas of interest for future research. They should not be used in isolation to guide treatment choices or public health policy.

\section{ORCID iD}

Tushar Sehgal http://orcid.org/0000-0001-7481-5550

\section{REFERENCES}

1 Marlar RA, Potts RM, Marlar AA. Effect on routine and special coagulation testing values of citrate anticoagulant adjustment in patients with high hematocrit values. $A m$ J Clin Pathol 2006;126:400-5.

2 Favaloro EJ, (Adcock) Funk DM, Lippi G. Pre-Analytical variables in coagulation testing associated with diagnostic errors in hemostasis. Lab Med 2012;43:1.2-10.

3 Magnette A, Chatelain M, Chatelain B, et al. Pre-Analytical issues in the haemostasis laboratory: guidance for the clinical laboratories. Thromb J 2016;14:49.

4 Lippi G, Guidi GC. Risk management in the preanalytical phase of laboratory testing. Clin Chem Lab Med 2007;45:720-7.

5 Gosselin RC, Marlar RA. Preanalytical variables in coagulation testing: setting the stage for accurate results. Semin Thromb Hemost 2019;45:433-48.

Copyright 2021 BMJ Publishing Group. All rights reserved. For permission to reuse any of this content visit

https://www.bmj.com/company/products-services/rights-and-licensing/permissions/

BMJ Case Report Fellows may re-use this article for personal use and teaching without any further permission.

Become a Fellow of BMJ Case Reports today and you can:

- Submit as many cases as you like

Enjoy fast sympathetic peer review and rapid publication of accepted articles

- Access all the published articles

Re-use any of the published material for personal use and teaching without further permission

Customer Service

If you have any further queries about your subscription, please contact our customer services team on +44 (0) 2071111105 or via email at support@bmj.com.

Visit casereports.bmj.com for more articles like this and to become a Fellow 